\title{
THE LAW EDUCATION AND MAKING THE BIRTH CERTIFICATE AS PROTECTION FORM FOR THE CHILDREN
}

Marlina $^{1}$, Mahmud Mulyadi ${ }^{2}$

\author{
1) Maternity and Child Department, Faculty of Nursing, Universitas Sumatera Utara \\ E-mail: marlina@usu.ac.id/linafulinsia@yahoo.com \\ ${ }^{2)}$ Maternity and Child Department, Faculty of Nursing, Universitas Sumatera Utara \\ E-mail: mahmudmulyadi@usu.ac.id
}

\begin{abstract}
The birth of a child is a gift and the happiness of parents. The birth is an important event in population administration. Each child must get clear and correct self identity. Birth certificate is an identity form of a child that needs to do by parents as a protection form for the child. The parents' understanding about birth certificate is still lacking especially in partner village. The condition creates an idea to do a law education and accompaniment to make birth certificate with involves the role of village official, provision districts and related agencies. The used method is delivered the material by tutorial lecture to the society by bringing Department of population and civil registration in making birth certificate by involving village official, provision districts and society to find the policy form to protect child with clear and correct self identity. The next stage is accompaniment in making birth certificate and cooperation all materials to the ownership of child as a protection for the children. The result of service shows creating an understanding of partner society in the ownership of birth certificate and the protection form of the child status and the marriage status, and the fulfillment of other requirement in making certificate as the guide book. The result of accompaniment and cooperation in Department of population and civil registration succeed to publish 61 marriage certificate from 67 couples which presents with 2 witnesses when notes in Department of population and civil registration from 123 application marriage certificate submitted. Next form the marriage certificate submitted to publish of birth certificate. The birth certificate which succeeds to be published 107 birth certificate from 162 application birth certificate submitted by society. The failure of submitted certificate because the lack of data, lack of requirement, the discrepancy data, and published the birth certificate.
\end{abstract}

Keyword: Education law, Birth certificate, Child

\section{PENDAHULUAN}

Kelahiran merupakan peristiwa yang membahagiakan bagi setiap keluarga dan merupakan peristiwa penting dalam kehidupan manusia yang harus di catatkan, namum terdapat kesalahan persepsi yang memandang pencatatan kelahiran hanya sebagai bagian dari pekerjaan teknis administratif. Pencatatan kelahiran seharusnya merupakan manifestasi dari hak asasi manusia. Masyarakat dan para birokrat pemerintahan harus memandang urusan KTP dan akta kelahiran bukan hanya urusan teknis administrasi kependudukan, akan tetapi merupakan hak anak yang harus dipenuhi. [1].
Pencatatan kelahiran adalah hak anak yang paling dasar yang seharusnya diberikan negara. Deklarasi Universal Hak Asasi Manusia menyatakan setiap orang mempunyai hak untuk diakui sebagai manusia di mana pun di depan hukum.[2] Pernyataan ini juga dipertegas dalam Kovenan Internasional mengenai Hak Sipil dan Politik. Dalam perspektif HAM, sebuah nama bersifat universal, terlepas dengan latar belakang politik, agama, dari orangtua mereka. Dalam perspektif tersebut pencatatan kelahiran merupakan kewajiban negara untuk mencatat kelahiran anak-anak di Indonesia. Konstruksi tersebut seharusnya menempatkan akta kelahiran sebagai sebuah dokumen yang amat penting dalam sebuah perkawinan sebagaimana 
Putusan Mahkamah Konstitusi No 46/PUUVII/2010 tanggal 17 februari 2012 tentang pasal 43 ayat (1) Undang-Undang Perkawinan.[3]

Menurut Peraturan presiden No. 25 Tahun 2008 tentang persyaratan dan tata cara pendaftaran penduduk dan pencatatan sipil adapun Fungsi utama dari Akta Kelahiran:[4]

1. Menunjukkan hubungan hukum antara si anak dengan orang tuanya secara hukum. Di dalam Akta Kelahiran tersebut disebutkan siapa bapak dan ibu dari si anak.

2. Merupakan bukti awal kewarganegaraan dan identitas diri pertama yang dimiliki sang anak. Akta kelahiran membuktikan bahwa si anak lahir di Indonesia dan menjadi Warga Negara Indonesia (WNI).

3. Kegunaan Akta Kelahiran:
a. Syarat untuk sekolah bagi si anak kelak.
b. Membauat identitas lain, seperti Kartu Kelurga atau Kartu Tanda Penduduk.
c. Mencari pekerjaan.
d. Menikah, dan lain-lain

Akta kelahiran adalah identitas diri anak yang wajib diberikan sejak kelahirannya. Akta Kelahiran adalah sebuah akta yang wujudnya berupa selembar kertas yang dikeluarkan Negara berisi informasi mengenai identitas anak yang dilahirkan, yaitu nama, tanggal lahir, nama orang tua serta tanda tangan pejabat yang berwenang. [5]

Menurut Undang-undang No.23 Tahun 2006 tentang Administrasi Kependudukan [6] yang diperbaharui dengan Undang-undang Nomor 24 tahun 2013 tentang Administrasi Kependudukan [7] akta kelahiran itu begitu besar manfaatnya, karena dapat kita lihat hampir setiap urusan kita membutuhkan akta kelahiran. Idealnya 60 hari setelah kelahiran ada dibuatkan akta kelahiran, namun masih banyak masyarAkat yang tidak melakukan hal tersebut. [8]

Pemerintah telah memberikan kemudahan dan pelayanan dengan tidak diminta pembayaran terhadap pembuatan akta yang ada serta prosedur dan syarat pembuatan akta sangat mudah dan jelas. yaitu KTP, Kartu Penduduk, Akta Perkawinan (buku nikah)ketntuan persyaratan pembuatan akta kelahiran dalam upaya memberikan perlindungan terhadap warga negara. [9]

Adapun caranya yaitu pemohon mengisi Formulir Surat Keterangan Kelahiran ditandatangani oleh pemohon dan diketahui oleh Kepala Desa/Lurah. Kepala Desa/Lurah berkewajiban meneruskan Formulir Surat Keterangan Kelahiran kepada UPTD Instansi Pelaksana untuk diterbitkan kutipan Akta Kelahiran. Pejabat Pencatatan Sipil pada Instansi Pelaksana/UPTD Instansi Pelaksana mencatatn dalam Register Akta Kelahiran dan menerbitkan Kutipan Akta Kelahiran dan menyampaikan kepada Kepala Desa/Lurah atau kepada pemohon.

Berdasarkan uraian diatas, tim pengabdian masyarakat dalam tugas Tri Darma Penguruan Tinggi tentang Pendidikan hukum dan Pembuatan Akta Kelahiran sebagai bentuk perlindungan terhadap anak di Desa Salam Hulu Kecamatan Pancur Batu dan Desa Suka Dame di Kecamatan Pancur Batu di Kabupaten Deli Serdang.

\section{METODE}

Kegiatan ini di laksanakan di Desa Hulu kecamtan pancur Batu dan Desa Suka Dame. Pemilihan lokasi ini dilakukan secara purpusive karena daera ini merupakan daerah yang letaknya Kabupaten Deli Serdang Sumatera Utara, yang memiliki keragaman penduduk dan agama. Agama yang ada Kristen, Islam, Budha dan Hindu, Pendudukan rata-rata memiliki pekerjaan bertani dan berladang, buruh tani padi dan 
sawit serta tukang bangunan. Suku yang ada di daerah ini suku mayoritas karo dan batak, ada juga Jawa, Minang dan melayu. Kehidupan masyarakatnya sangat komplek sekali. Tingkat Pendidikan di kedua desa ini bisa dikategorikan masih rendah, karena perhatian dan keinginan memajukan anak ke tingkat pendidikan yang lebih tinggi masih kurang. Hetrogennya penduduk, dan kompleknya mata pencaharian dan kegiatan masyarakat di dua desa menyebabkan kompleksnya juga permasalahan yang ada di desa tersebut. Adapun metode kegiatan yang dilakukan yaitu dengan Pelatihan dengan Ceramah dan turotial tentang peraturan terkait tentang pembuatan akta kelahiran dan perlindungan terhadap anak melalui pembagian buku pedoman, selanjuntya tim melakukan pengumpulan dan seleksi syarat untuk membuatan akta kelahiran. Setelah syarat di kumpulkan lalu tim mengadakan kerja sama dengan dinas kependudukan dan catatan sipil. Tim menyerahkan syarat ke dinas untuk selanjutnya di proses dalam pembuatan akta kelahiran. Selanjutnya tim mengantar, mengambil dan menyerahkan akta perkawinan dan akta kelahiran yang telah terbit kepada masyarakat.

\section{HASIL DAN PEMBAHASAN}

Pengabdian pendidikan hukum dan pembuatan akta kelahiran sebagai bentuk perlindungan terhadap anak yang dilaksanakan di Desa Suka Dame kecamatan Kuntalimbaru dan Desa Hulu Kecamatan Pancur Batu. Pengabdian ini dilakukan sebagai upaya untuk memberikan perlindungan hukum terhadap anak sebagaimana yang dikemukanan dalam Undang-Undang No. 35 Tahun 2014 tentang Perlindungan Anak, [10] menyatakan bahwa anak berhak mendapatkan perlindungan terhadap tumbuh kembang anak sesuai dengan lingkungan, usia dan jiwanya. Pengabdian ini merupakan satu bentuk perlindungan anak. Penbdian ini berjalan sesuai dengan rencana pengabdian yang dilakukan, meskipun tim pengabdian harus melalukan kegiatan ekstra lebih banyak waktu dan perhatian serta pendampingan yang melewati batas awal dari kegiatan semula, dikarenakan masyarkat belum seluruhnya memiliki kesadaran pentingnya akte kelahiran, sehingga tim pengabdian harus mengetuk satu persatu rumah penduduk di dampingi oleh pihak aparat desa dan penduduk yang aktif dalam masyarakat. Desa suka Dame yang terdiri dari masyarakat mayoritas karo dan Batak maka tim didampingi oleh sekretaris desa, ibu Ratnawati dan ibu Mardiana yang memiliki kemampuan bahasa Karo dan Batak. Kades dan kepala dusun juga ikut membantu secara kontinu agar masyarakat mau mengurus akta kelahiran. Setelah diselusuri dan di bujuk serta di berikan pengarahan serta penjelasan akhirnya masyarkat peduli dan sadar untuk mengurus akta kelahiran anaknya. Tim pengabdian dan pihak desa di dampingin warga yang aktif mendatangi rumah untuk mengambil berkas persyaratan akta kelahiran menginggat waktu pengabdian yang terbatas sampai bulan oktober akhir. Untuk mencapai tujuan tersebut tim pengabdian seminggu 4-6 kali datang kelokasi pengabdian untuk menjumpai warga guna menanyakan dan meminta berkas persyaratan.

Awalnya berkas yang terkumpul sebanyak 57 berkas dari desa Suka dame dan 40 dari desa hulu di bawa oleh tim ke dinas kependudukan deli serdang. Selanjuntya Dinas memeriksa berkas tersebut dan ternyata berkas di pulangkan di karenakan banyaknya terjadi ketidak sesuaian antara data dengan data pendukung lainnya, misalnya nama yang tidak sama antara akta perkawinan, surat nikah, KK dan KTP bahkan surat keterangan lahir disamping itu persoalan yang paling pokok dari pembuatan akta kelahiran tersebut adalah rata-rata akta perkawinan yang di miliki adalah akta perkawinan dari gereja belum dari dinas kependudukan dan catatan sipil. Kondisi tersebut tim harus memulangkan berkas dan mengumpulkan warga untuk hadir dalam pertemuan ketiga di balai desa mitra untuk menjelaskan kekurangan dan 
persoalan data yang tidak sesuai antara satu data dengan data yang lainnya. Ketua pengabdian meminta agar data disesuaikan terlebih dahulu diantaranya menganti KK, Menganti KTP atau ganti surat Pasu-pasu gereja. Tim juga membantu masyarakat mitra untuk perbaikan data agar cepat dan bekerjasama dengan pihak desa, kecamatan dan dinas agar proses pengantian data tersebut di bantu. Proses ini tim membutuhkan waktu tambahan 2 minggu mendampingi dan memantau perubahan data tersebut memlakukan kegiatan tambahan yaitu pembuatan akta perkawinan.

Seiring dengan itu ketua pengabdian mengadakan komunikasi dengan dinas kependudukan dan catatan sipil untuk membantu dan bekerjasama dengan tim pengabdian. Akhirnya tim berhasil meminta bantuan kepada Ketua Dinas Kependudukan dan Catatan Cipil untuk hadir kelokasi pengabdian dalam rangka membuat akta perkawinan. Kehadiran tim perwakilan dari dinas Kependudukan dan Catatan Siipil Deli Serdang tersebut merupakan syarat guna mempermudah proses pembuatannya dan membantu masyarakat agar tidak harus datang ke dinas lubuk pakam yang jaraknya sangat jauh dari desa mitra dan biaya yang besar buat pendudukan. Maka pada Hari Sabtu tanggal 14 Juli 2018 mulai jam 08:30 - 17.00 WIB tim betempat di Desa suka Dame Dinas kependudukan mendata dan mencatatkan akta perkawinan masyarakat dari kedua desa mitra tersebut. Pertemuan tersebut di hadiri 100 pasangan suami istri pembuat akta perkawinan beserta saksisaksinya yang masing masing 2 orang, pihak dari desa suka dame sebagai mitra dan kepala-kepala dusun dari desa mitra serta pendeta. Pertemuan tersebut menghasilkan 68 berkas lengkap dan memenuhi syarat yang bisa di bawa ke lubuk pakam oleh dinas untuk di proses. Sebagian berkas tidak dapat di proses karena masih banyak data yang tidak lengkap dan tidak adanya kesesuai antara data dan data pendukung lainnya. Selanjutnya tim menunggu selama 1 bulan dan senin di dapatkan hasil bahwa dari 68 data yang masuk, 10 di pulangkan kembali karena setelah diteliti masih memiliki ketidak sesuai data dengan data pendukung, bahkan adanya ketidak tepatan antara perkawinan dan surat pendukung pasu-pasu dalam perkawinan tersbut. 10 data tersebut di kembalikan ke pada masyarakat untuk di perbaiki dan di cari data sebenarnya dan di dukung oleh data pendukung lainnya, diantaranya masyarkat harus mengambil surat pasu-pasu kembali dengan mencocokan nama di surat pasupasu dengan KTP dan KK serta surat baktisnya. Dari 10 data yang di pulangkan ada 4 yang berhasil di masukan kembali untuk di proses lanjutan sedangkan sisanya tidak bisa karena bermasalah karena ada yang pindah agama, sehingga hasil semua akta perkawian yang dapat ditebitkan adalah 61 akta perkawinan.

Selama proses pembuatan akta perkawinan, bagi data yang sudah lengkap data untuk pembuatan akta kelahirannya terus berjalan dan telah terbit, pada bulan juli data 15 akta kelahiran dari dinas kependudukan dan catatan sipil untuk desa suka dame dan menyusul 87 data yang lagi dalam proses akte di dinas catatan sipil yang lulus 61 akta kelahiran, selanjutnya bulan september 17 akta, oktober 15 akta, November 14 akta kelahiran total akta yang terbit selama pengabdian 107 akta kelahiran dan 61 akta perkawinan.

\section{Luaran yang Dicapai}

Setelah melaksanakan pengabdian di lokasi, maka diperoleh beberapa kegiatan yang di muat dalam media promosi berupa buku dan video kegiatan serta jurnal.

a. Buku Pedoman.

Sebagaimana mestinya, buku ini memuat tentang fungsi utama akta kelahiran, kegunaan akta kelahiran, persyaratan akta kelahiran, tata cara pembuatan akta kelahiran serta persoalan kegagalan pembuatan akta kelahiran. 
b. Video Kegiatan.

Video ini merupakan kumpulan kegiatan pengabdian yang dilakukan oleh tim dengan melibatkan masyarkat dan tokoh masyarakat dalam upaya untuk memberikan pemahaman, pendidikan hukum serta kesadaran hukum masyarakat terhadap penerbitan akta kelahiran sebagai bentuk perlindungan terhadap anak.

c. Jurnal ilmiah.

Jurnal tersebut sebagai bentuk promosi terkait kegiatan pengabdian yang meliputi latar belakang dilakukannya pengabdian, situasi kondisi lingkungan mitra, metode kegiatan yang dilakukan serta hasil dari pengabdian yang dilakukan.

\section{d. Terbit Akta kelahiran dan Akta Perkawinan.}

\section{PENUTUP}

Akta kelahiran merupakan dokumen penting tentang identitas anak, akta kelahiran sangat dibutuhkan anak dalam upaya memberikan perlindungan terhadap diri anak. Pemerintah telah memberikan kemudahan dan keringanan pengurusan akta kelahiran. Pengabdian yang ini telah memberikan pemahaman pentingnya akta kelahiran bagi anak, tujuan dan manfaat akta kelahiran, cara dan syarat pengajuan akta kelahiran serta faktor penyebab kena akta kelahiran itu tidak terbit ketika diajukan. Pengabdian ini juga telah memberikan kerjasama anara dinas dan pimpinan desa untuk bekerjasama dalam upaya mempermudah dan mempelancar proses pembuatan akta kelahiran. Kepedulian dan kerjasama jajaran kecamatan, jajaran desa dan masyarakan akan membantu dna mendorong perbuatan akta kelahiran sehingga setiap anak yang lahir akan memiliki identitas yang benar dan sah menurut hukum. Semoga dimasa yang akan data setelah pengabdian ini dilakukan kerjasama dan pemahaman serta kesadaran masyarkat tentang akta kelahiran sebagai bentuk perlindungan terhadap anak akan terus terjalin dengan baik dan efektif sehingga semua program pendataaan secara umum berjalan dengan cepat, tepat dan akuran demi perbaikan kualitas masa depan anak-anak bangsa.

\section{UCAPAN TERIMA KASIH}

Terima kasih kepada Lembaga Penelitian Pengabdian pada Masyarakat Universitas Sumatera Utara atas pendanaan pengabdian ini berdasarkan kontrak Nomor 172/UN5.2.3.2.1/PPM/2018, Tanggal 16 April 2018 tentang Pendidikan Hukum dan Pembuatan Akta Kelahiran sebagai Bentuk Perlindungan Terhadap Anak.

\section{DAFTAR PUSTAKA}

Henry S. Siswosoediro, Mengurus Surat-Surat Kependudukan (identitas Diri), Jakarta Visimedia, 2008.

Maidin Gultom, Perlindungan Hukum terhadap Anak dan Perempuan, Penerbit PT Refika Aditama, Bandung, 2014.

Putusan Mahkamah Konstitusi No 46/PUUVII/2010 tanggal 17 februari 2012 tentang pasal 43 ayat (1) UndangUndang Perkawinan

Peraturan presiden No. 25 Tahun 2008 tentang persyaratan dan tata cara pendaftaran penduduk dan pencatatan sipil.

Undang-undang Nomor 23 Tahun 2006 tentang Administrasi kependudukan.

Undang-undang Nomor 24 tahun 2013 tentang Administrasi Kependudukan

Ruslan H Prawijo, Kependudukan Teori Fakta dan Masalah, Penerbit Alumni, Bandung, 2005

Rusli, Said, Pengantar Ilmu Kependudukan, LP3 ES, Jakarta, 2005. 
Marlina et.al. The Law Education And Making The Birth Certificate As Protection Form For The Children

Sudikno Mertokusumo, Pengantar Hukum Perdata Tertulis (BW), Sinar Grafika, Jakarta, 2001.

Undang-Undang No. 35 Tahun 2014 Tentang Perlindungan Anak 